\title{
Impact of Nutrition Education on Knowledge, Attitude, Practices and Beliefs of Adolescent Girls Belonging to Rural and Urban Area of District Kurukshetra
}

\author{
Gurpreet Arora ${ }^{1}$, G. K. Kochar ${ }^{2}$ \\ ${ }^{1}$ Department of Home Science, Kurukshetra University, Kurukshetra, Haryana, India \\ ${ }^{2}$ Department of Food and Nutrition, Central University of Haryana, Haryana, India \\ Email address: \\ Mail2gurpreetarora@gmail.com (G. Arora), kocharcup@gmail.com (G. K. Kochar)
}

\section{To cite this article:}

Gurpreet Arora, G. K. Kochar. Impact of Nutrition Education on Knowledge, Attitude, Practices and Beliefs of Adolescent Girls Belonging to Rural and Urban Area of District Kurukshetra. International Journal of Nutrition and Food Sciences. Vol. 5, No. 4, 2016 , pp. $278-283$. doi: $10.11648 /$ j.ijnfs.20160504.17

Received: June 3, 2016; Accepted: June 15, 2016; Published: June 30, 2016

\begin{abstract}
One hundred fifty girls in the age group of 13-19 years were selected randomly from government schools of rural and urban area of district kurukshetra, Haryana and surveyed for their attitude towards food, knowledge and awareness about nutrition, behaviour and practices adopted to maintain nutritional status. Nutrition education was imparted to the subjects after assessing their basic nutrition knowledge. Nutrition education improved their awareness about nutrition and health significantly.
\end{abstract}

Keywords: Nutrition, Diet, Knowledge, Attitude, Dietary Pattern, Adolescent Girls

\section{Introduction}

Adolescent nutritional problem is common throughout the country. They have to happenstance a sequence of serious nutritional trials not only affecting their growth and development but also their livelihood as adults. Yet adolescents remain a largely ignored and hard to reach population especially girls. Thus it is not astonishing that adolescent girl population who are "mother to be" is if considers as the most important section on which the future of nation depends. (Measham, A. R., 2000 and Rao, S., 1996) Adolescent growth and development is closely linked to the diet they receive during childhood and adolescence. Disagreeable food conducts and nutrition-related practices, which are often based on scarce knowledge, customs and myths or meager understanding of the association between diet and health, can harmfully affect their nutritional status. if adequate motivation is delivered, adolescents can embrace healthier diets and improve their nutritional health by changing their food and nutrition attitudes, knowledge and practices. This necessitates a rudimentary knowledge of what constitutes a nutritious diet and how people can best meet their nutritional needs from available resources. Hence nutrition education is applied to emphasize specific nutrition-related practices or behaviours to change habits that contribute to poor health; this is done by crafting a stimulus for change among people, to initiate desirable food and nutrition behaviour for advancement and sentinel of good health. Keeping this in view, the present study has been expounded to understand the impact of nutrition education on knowledge, attitude, practices and beliefs of adolescent girls.

\section{Material and Methods}

Selection of the Subjects: one hundred fifty adolescent girls between 13-19 years old, studying in standards viii, ix and xi were selected randomly from government schools of rural and urban area of district kurukshetra, Haryana. 


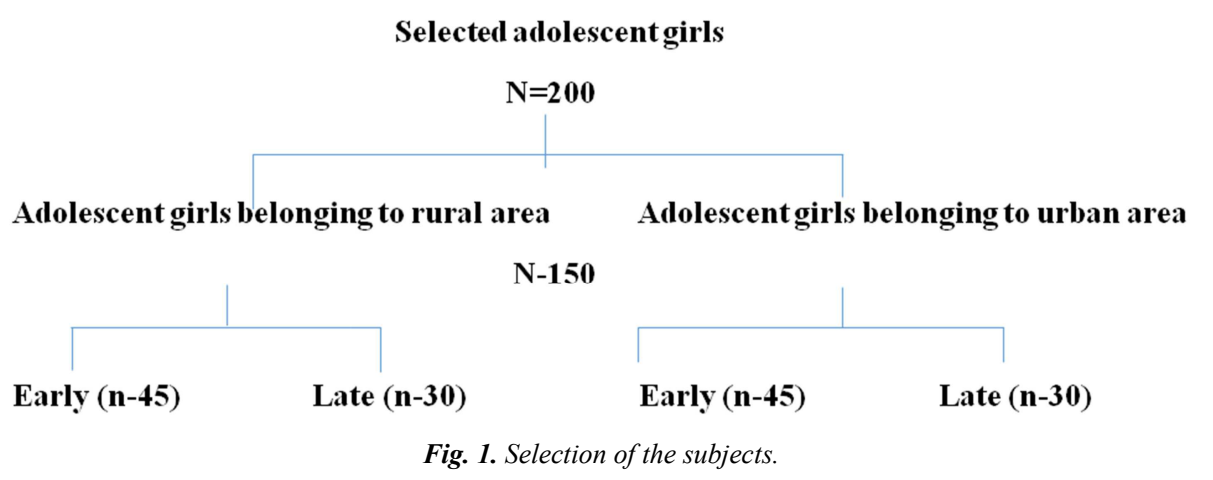

General Information: Information regarding family background, qualification and occupation of mothers and fathers, caste and religion were collected through interview method.

Nutrition Knowledge: For adjudicating current level of nutrition understanding, a questionnaire comprising list of questions relating to calories, carbohydrates, proteins, macro and micro nutrients, attitude towards conservation of nutrients during preparation, during cooking and during storage, awareness about anaemia, beliefs related to food, fad and fallacies, food hygiene and sanitation was supplied to each subjects for filling before imparting nutrition education. For evaluating the level of nutrition knowledge one score was awarded for right and zero for wrong answer of each question.

Nutrition Education: After adjudicating the level of nutrition knowledge of the subjects, nutrition education was imparted to all of the subjects in school classrooms twice a week, for the period of three months and once fortnightly for the subsequent month. Education was imparted to these female subjects belonging to rural and urban area through lectures and making use of leaflets, pamphlets and charts, tape recorder, movie, projectors and demonstration of recipes, related to nutrition and anaemia. The topics covered for imparting nutrition education were functions and importance of food; balanced diet; nutrient - their functions and requirements. In addition, right cooking practices for conservation of nutrients, methods of improving iron status, cheap and locally available rich food sources of iron, improve nutritive value of food through germination and fermentation, food hygiene and sanitation etc were also covered.

Gain in Nutrition Knowledge: After imparting nutrition education, above developed questionnaire was again given to all the subjects for filling to adjudge the gain in level of nutrition knowledge of each subject. For evaluating the level of nutrition knowledge one score was awarded for right and zero for wrong answer of each question. Gain in nutrition knowledge and quantum of improvement was calculated as follows:

Gain in Nutrition Knowledge $=$ Score in Post test - Score in Pre-test.

Quantum of Improvement $=$ Post test score $/$ Pre- test score

Dietary assessment: Information related to diet were collected by questionnaire cum interview method. questions related to diet consumed, number of meals taken and skipped and type of meal skipped was recorded. Dietary intake was adjudicated by $24 \mathrm{hr}$. recall method for three consecutive days. The dietary intake was recorded before and after imparting nutrition education. To facilitate an accurate estimate of food consumed by the subjects, a set of household containers were standardised. Then the mean of three days of different food groups like cereals, pulses, green leafy vegetables etc; were calculated using food composition tables/ nutritive value book (gopalan et al., 1993; Kaur and Bhatt, 1986).

\section{Results and Discussion}

Educational status of fathers: Educational status is an important indicator to judge the socio economic status as well as nutritional status of that community. Among all the selected subjects, $43 \%$ of the fathers were primary educated, $28 \%$ were secondary educated, $21 \%$ were uneducated and the remaining $8.0 \%$ were graduates or post graduates and above. Among uneducated fathers, 31\% were from rural area and $11 \%$ were from urban area which means rural areas have a large proportion of uneducated fathers. In urban area, maximum proportion of the fathers $40 \%$ were secondary educated whereas in rural area, maximum proportion of the fathers $52 \%$ were primary educated. It has been observed that the percentage of fathers who were graduate or post graduate and above was very less contributing $1 \%$ in rural areas and $14 \%$ in urban areas.

Educational status of mothers: Among all the selected subjects, $42.5 \%$ of the mothers were primary educated, $23 \%$ were secondary educated, $33 \%$ were uneducated and the remaining (3\%) were graduates. Among uneducated mothers, $42 \%$ were from rural area and $24 \%$ were from urban area which means rural areas have a large proportion of uneducated mothers. In rural area, maximum proportion of the mothers $(42 \%)$ were uneducated whereas in urban area, maximum proportion of the mothers $(34 \%)$ were primary educated. It has been observed that the percentage of mothers who were graduate was very less.

Occupational status of fathers: Fathers of $63 \%, 18.5 \%, 10 \%$ and $2.5 \%$ were involved in agricultural activities (as labourers), in their own business, private jobs and government jobs respectively. $7.5 \%$ of the total were unemployed. In rural area, only $1 \%$ father was employed in government job whereas in urban area, this figure was $4 \%$. In rural and urban areas, maximum proportion of fathers were employed as labourer and figure was $62 \%$ and $64 \%$ respectively. 
Occupational status of mothers: Among all the selected subjects, $47 \%, 18 \%, 0.5 \%, 34 \%$ of the mothers were housewives, labourers, involved in their business, doing jobs as maids. In rural areas, a large proportion of the mothers were housewives contributiong $55 \%$. None of the mother was engaged in government jobs from both areas. In rural areas, $19 \%$ of the mothers were labourers whereas this figure is less (17) when urban areas were seen.

Table 1. Family Profile of Urban and Rural Adolescent Subjects of District Kurukshetra.

\begin{tabular}{|c|c|c|c|c|c|c|c|}
\hline \multirow{2}{*}{ parameters } & \multicolumn{3}{|c|}{ Early adolescence n-120 } & \multicolumn{3}{|c|}{ Late adolescence $\mathbf{n - 8 0}$} & \multirow{2}{*}{ Grand total n-200 } \\
\hline & Rural n-60 & Urban n-60 & Total n-120 & Rural n-40 & Urban n-40 & Total n-80 & \\
\hline \multicolumn{8}{|l|}{ Type of family } \\
\hline Nuclear & $32(53.33)$ & $54(90)$ & $86(71.7)$ & $24(60)$ & $30(75)$ & $54(67.5)$ & $140(70)$ \\
\hline Joint & $28(46.67)$ & $6(10)$ & $34(28.3)$ & $16(40)$ & $10(25)$ & $26(32.5)$ & $60(30)$ \\
\hline \multicolumn{8}{|l|}{ Religion } \\
\hline Hindu & $51(85)$ & $54(90)$ & $105(87.5)$ & $29 \&(72.5)$ & $31(77.5)$ & $60(75)$ & $165(82.5)$ \\
\hline Sikh & $7(11.67)$ & $5(8.33)$ & $12(10.0)$ & $11(27.5)$ & $7(17.5)$ & $18(22.5)$ & $30(15)$ \\
\hline Muslim & - & $1(1.67)$ & 1 & - & - & - & $1(0.5)$ \\
\hline other & - & $2(3.33)$ & 2 & - & $2(5)$ & 2 & $4(2.0)$ \\
\hline \multicolumn{8}{|c|}{ Educational and Occupational Status of Parents } \\
\hline \multicolumn{8}{|c|}{ Education of Father } \\
\hline Uneducated & $17(28.33)$ & $9(15)$ & $26(21.7)$ & $14(35)$ & $2(5.0)$ & $16(20)$ & $42(21)$ \\
\hline Primary & $34(56.6)$ & $18(30)$ & $52(43.3)$ & $18(45)$ & $16(40)$ & $34(42.5)$ & $86(43)$ \\
\hline Secondary & $8(13.33)$ & $22(36.7)$ & $30(25.0)$ & $8(20)$ & $18(45)$ & $26(32.5)$ & $56(28)$ \\
\hline Graduate & $1(1.7)$ & $11(18.7)$ & $12(10.0)$ & - & $3(7.5)$ & $3(3.7)$ & $15(7.5)$ \\
\hline \multicolumn{8}{|l|}{ Education of Mother } \\
\hline Uneducated & $22(36.7)$ & $13(21.7)$ & $35(29.1)$ & $20(50.0)$ & $11(27.5)$ & $31(38.7)$ & $66(33)$ \\
\hline Primary & $29(48.3)$ & $32(53.3)$ & $61(50.8)$ & $12(30)$ & $12(30)$ & $24(30)$ & $85(42.5)$ \\
\hline Secondary & $9(15)$ & $13(21.7)$ & $22(18.3)$ & $8(20)$ & $16(40)$ & $24(30)$ & $46(23)$ \\
\hline Graduate & - & $2(3.4)$ & $2(1.7)$ & - & $1(2.5)$ & 1 & $3(1.5)$ \\
\hline Post Graduate/Above & - & - & - & - & - & - & - \\
\hline \multicolumn{8}{|l|}{ Occupation of Father } \\
\hline Unemployed & $3(5.0)$ & $5(8.33)$ & $8(6.7)$ & $4(10)$ & $3(7.5)$ & $7(8.75)$ & $15(7.5)$ \\
\hline Private Job & $8(13.3)$ & $6(10)$ & $14(11.7)$ & $3(7.5)$ & $3(7.5)$ & $6(7.5)$ & $20(10)$ \\
\hline Government Job & - & $2(3.3)$ & $2(1.7)$ & $1(2.5)$ & $2(5.0)$ & $3(3.7)$ & $5(2.5)$ \\
\hline Labourer & $35(58.3)$ & $36(60)$ & $71(59.1)$ & $27(67.5)$ & $28(70)$ & $55(68.7)$ & $126(63)$ \\
\hline Self Employed/ Business & $14(23.3)$ & $13(21.7)$ & $27(22.5)$ & $6(15)$ & $4(10)$ & $10(12.5)$ & $37(18.5)$ \\
\hline \multicolumn{8}{|l|}{ Occupation of Mother } \\
\hline Housewife & $33(55.0)$ & $22(36.7)$ & $55(45.9)$ & $22(55)$ & $17(42.5)$ & $39(48.7)$ & $94(47)$ \\
\hline Labourer & $8(13.3)$ & $12(20.0)$ & $20(16.7)$ & $11(27.5)$ & $5(11.5)$ & $16(20)$ & $36(18)$ \\
\hline Self Employed/ Business & $1(1.67)$ & - & $1(0.83)$ & - & - & - & $1(0.5)$ \\
\hline Other & - & - & - & - & - & - & - \\
\hline
\end{tabular}

Table 2. Dietary patterns of Adolescent Subjects of Rural and Urban Area of District Kurukshetra.

\begin{tabular}{|c|c|c|c|c|c|c|c|c|}
\hline \multirow{3}{*}{$\begin{array}{l}\text { particulars } \\
\text { Dietary habits }\end{array}$} & \multicolumn{4}{|c|}{ Adolescents belonging to rural area n-75 } & \multicolumn{4}{|c|}{ Adolescents belonging to urban area $n-75$} \\
\hline & \multicolumn{2}{|c|}{$\begin{array}{l}\text { Before imparting nutrition } \\
\text { education }\end{array}$} & \multicolumn{2}{|c|}{$\begin{array}{l}\text { after imparting nutrition } \\
\text { education }\end{array}$} & \multicolumn{2}{|c|}{$\begin{array}{l}\text { Before imparting nutrition } \\
\text { education }\end{array}$} & \multicolumn{2}{|c|}{$\begin{array}{l}\text { after imparting nutrition } \\
\text { education }\end{array}$} \\
\hline & No. & $\%$ & No. & $\%$ & No. & $\%$ & No. & $\%$ \\
\hline Vegetarian & 59 & 78.7 & 48 & 64.0 & 50 & 66.7 & 37 & 49.3 \\
\hline Non-vegetarian & 8 & 10.7 & 13 & 17.3 & 13 & 17.3 & 17 & 22.7 \\
\hline Ova-tarian & 8 & 10.7 & 14 & 18.7 & 12 & 16.0 & 21 & 28.0 \\
\hline Yes & 41 & 54.7 & 54 & 72.0 & 32 & 42.7 & 41 & 54.7 \\
\hline No & 19 & 25.3 & 10 & 13.3 & 38 & 50.7 & 23 & 30.7 \\
\hline Sometimes & 15 & 20.0 & 11 & 14.7 & 15 & 20.0 & 11 & 14.7 \\
\hline \multicolumn{9}{|c|}{ Do you skip Meals } \\
\hline Yes & 53 & 70.6 & 24 & 32 & 61 & 81.3 & 22 & 29.3 \\
\hline No & 22 & 29.3 & 51 & 68 & 14 & 18.6 & 53 & 70.6 \\
\hline \multicolumn{9}{|c|}{ Type of meal skipped } \\
\hline Lunch & 11 & 20.7 & 6 & 25 & 10 & 16.3 & 6 & 27.2 \\
\hline Dinner & 3 & 5.6 & 0 & 0 & 6 & 9.8 & 0 & 0 \\
\hline
\end{tabular}


Table 3. Knowledge about nutrition among Adolescent Subjects of Rural and Urban Area of District Kurukshetra.

\begin{tabular}{|c|c|c|c|c|c|c|c|c|}
\hline \multirow{3}{*}{$\begin{array}{l}\text { particulars } \\
\text { Awareness } \\
\end{array}$} & \multicolumn{4}{|c|}{ Adolescents belonging to rural area n-75 } & \multicolumn{4}{|c|}{ Adolescents belonging to urban area n-75 } \\
\hline & \multicolumn{2}{|c|}{$\begin{array}{l}\text { Correct responses } \\
\text { before imparting } \\
\text { nutrition education }\end{array}$} & \multicolumn{2}{|c|}{$\begin{array}{l}\text { Correct responses } \\
\text { after imparting } \\
\text { nutrition education }\end{array}$} & \multicolumn{2}{|c|}{$\begin{array}{l}\text { Correct responses } \\
\text { before imparting } \\
\text { nutrition education }\end{array}$} & \multicolumn{2}{|c|}{$\begin{array}{l}\text { Correct responses } \\
\text { after imparting } \\
\text { nutrition education }\end{array}$} \\
\hline & No. & $\%$ & No. & $\%$ & No. & $\%$ & No. & $\%$ \\
\hline \multicolumn{9}{|l|}{ calories } \\
\hline Energy yielding foods & 20 & 26.7 & 51 & 68 & 11 & 14.7 & 59 & 78.7 \\
\hline Chief function of carbohydrates & 17 & 22.7 & 66 & 88 & 26 & 34.7 & 58 & 77.3 \\
\hline \multicolumn{9}{|l|}{ Proteins } \\
\hline Body building foods & 16 & 21.3 & 55 & 73.3 & 19 & 25.3 & 54 & 72 \\
\hline Foods rich in protein & 29 & 38.7 & 61 & 81.3 & 30 & 40 & 65 & 86.7 \\
\hline $\begin{array}{l}\text { Good substitute of meat for vegetarians } \\
\text { vitamins }\end{array}$ & 19 & 25.3 & 52 & 69.3 & 27 & 36 & 58 & 77.3 \\
\hline Fat soluble vitamins & 22 & 29.3 & 49 & 65.3 & 22 & 29.3 & 58 & 77.3 \\
\hline Vitamin enhances absorption of calcium & 11 & 14.7 & 59 & 78.7 & 26 & 34.7 & 55 & 73.3 \\
\hline Most sensitive vitamin to heat & 20 & 26.7 & 53 & 70.7 & 17 & 22.7 & 57 & 76 \\
\hline
\end{tabular}

Table 4. Fad and fallacies among Adolescent Subjects of Rural and Urban Area of District Kurukshetra.

\begin{tabular}{|c|c|c|c|c|c|c|c|c|}
\hline \multirow{3}{*}{$\begin{array}{l}\text { particulars } \\
\text { Awareness } \\
\end{array}$} & \multicolumn{4}{|c|}{ Adolescents belonging to rural area n-75 } & \multicolumn{4}{|c|}{ Adolescents belonging to urban area $n-75$} \\
\hline & \multicolumn{2}{|c|}{$\begin{array}{l}\text { Correct responses before } \\
\text { imparting nutrition education }\end{array}$} & \multicolumn{2}{|c|}{$\begin{array}{l}\text { Correct responses after } \\
\text { imparting nutrition education }\end{array}$} & \multicolumn{2}{|c|}{$\begin{array}{l}\text { Correct responses before } \\
\text { imparting nutrition education }\end{array}$} & \multicolumn{2}{|c|}{$\begin{array}{l}\text { Correct responses after imparting } \\
\text { nutrition education }\end{array}$} \\
\hline & No. & $\%$ & No. & $\%$ & No. & $\%$ & No. & $\%$ \\
\hline \multicolumn{9}{|c|}{ Jaggery is hot food \& result in frequent menstruation. } \\
\hline Yes & 29 & 38.7 & 8 & 10.7 & 27 & 36 & 8 & 10.7 \\
\hline No & 14 & 18.7 & 59 & 78.7 & 24 & 32 & 61 & 81.3 \\
\hline Don't know & 32 & 42.7 & 8 & 10.7 & 34 & 45.3 & 6 & 8 \\
\hline \multicolumn{9}{|c|}{ Egg is responsible for early menstruation. } \\
\hline Yes & 39 & 52 & 10 & 13.3 & 25 & 33.3 & 10 & 13.3 \\
\hline No & 14 & 18.7 & 49 & 65.3 & 29 & 38.6 & 57 & 76 \\
\hline Don't know & 22 & 29.3 & 16 & 21.3 & 21 & 28 & 8 & 10.7 \\
\hline \multicolumn{9}{|c|}{ Excess of iron makes bone brittle. } \\
\hline Yes & 24 & 32 & 7 & 9.3 & 26 & 34.7 & 8 & 10.7 \\
\hline No & 13 & 17.3 & 62 & 82.7 & 22 & 29.3 & 60 & 80 \\
\hline Don't know & 38 & 50.7 & 6 & 8 & 27 & 36 & 7 & 9.3 \\
\hline Yes & 29 & 38.6 & 7 & 9.3 & 24 & 32 & 2 & 2.6 \\
\hline No & 13 & 17.3 & 62 & 82.7 & 24 & 32 & 68 & 90.7 \\
\hline Don't know & 33 & 44 & 6 & 8 & 27 & 36 & 5 & 6.6 \\
\hline
\end{tabular}

Table 5. Awareness about health among Adolescent Subjects of Rural and Urban Area of District Kurukshetra.

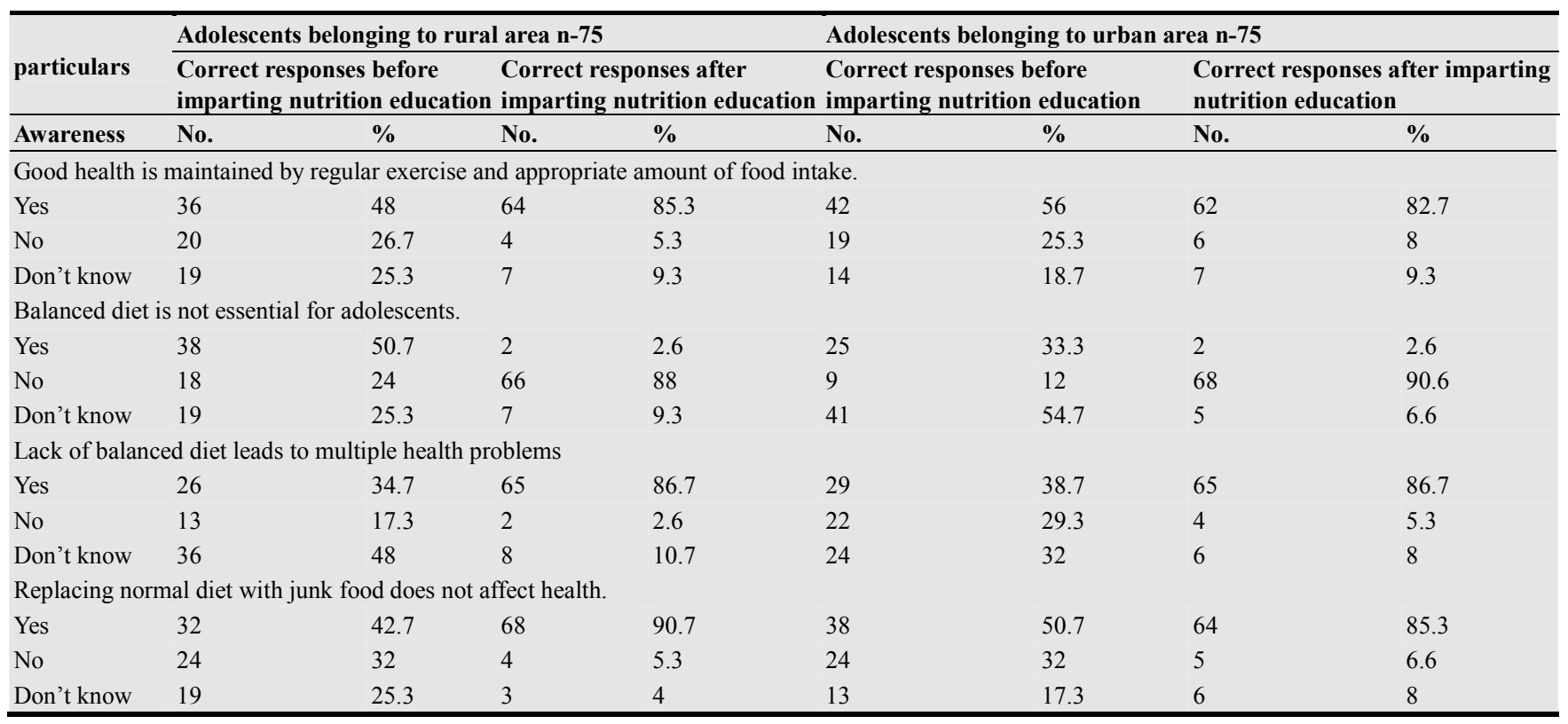


Dietary Habits: The outcome of nutrition education is strikingly visible as there was an improvement in the dietary habits of the female adolescent subjects belonging to rural and urban area. (Table 2). There was an increase in no. of girls who turned ova-tarian (from 8 to 14) in rural area and from (12 to 21$)$ in urban area as well as nonvegetarian (from 8 to 13) in rural area and (13 to 17) in urban area after imparting nutrition education. Most of the subjects belonging to rural area (54) as compared to urban area (41) started taking packed lunch to school with them. Meal skipping was found to be common practice among female subjects belonging to urban are (61) as compared to rural area (52). After imparting nutrition education, a drastic decrease was seen in skipping of meals in rural (24) and urban area (22). breakfast and lunch were found to be most frequently missed meals in the female subjects belonging to rural and urban area. However, after imparting nutrition education, practice of skipping breakfast reduced (from 39 to 18) in female subjects belonging to rural area and (from 45 to 16) in female subjects belonging to urban area. Similarly, skipping of lunch by the respondents belonging to rural area and urban area was reduced from 11 to 6,10 to 6 respectively.

Awareness about nutrition: a noticeable increase in awareness about nutrition was seen after imparting nutrition education to female adolescent subjects belonging to rural and urban area. Before imparting nutrition the correct responses of subjects belonging to rural and urban area about awareness of calories was 20,17, 25 and 11, 26, 24. After imparting nutrition education the correct responses changed to 51, 66, 68 and 59, 58,61. responses for awareness about proteins increased in female subjects belonging to rural area and urban area from 16, 29, 29 to 55, 61, 52 and from 19, 30, 27 to $52,65,38$ respectively, from $22,11,20$ to $49,59,53$ and from 22, 26, 17 to 58, 55, 57 respectively. Awareness about vitamins was seen increased significantly in the subjects belonging to rural and urban area from $22,11,20$ to 49, 59, 53 and 22, 26, 17 to 58, 55, 57 respectively.

Awareness about health: An increase in awareness about health was noticed after imparting nutrition education to female adolescents belonging to both areas. Responses for awareness about good health and balanced diet increased in subjects belonging to rural and urban area from 36, 42 to 64,62 and from 18,9 to 66,68 respectively. Awareness about junk food was seen increased significantly in the subjects.

Fad and fallacies: fad and fallacies about food continue to exist today in significant proportion, and they can deprive the believer of important elements of nutrition during adolescence. females are more likely to adhere to food taboos than men, which makes them more vulnerable to malnutrition. A noticeable decrease in believe about food myths has been seen in female adolescent subjects belonging to rural and urban area after imparting nutrition education about intake of foods during menstruation.

\section{Conclusion}

The present study clearly indicates a strong relation between nutrition education and the rise in the level of knowledge and awareness among the female adolescent students, who display strong enthusiasm for learning new concepts concerning their betterment.

\section{Recommendation}

It is strongly recommended that more such nutrition education programs at community level can be used to disseminate nutrition awareness and facilitate improvement of the nutritional status of the masses.

\section{References}

[1] Isobel R Contento PhD CDN 176 Asia Pac J Clin Nutr 2008; 17 (1): 176-179 Review Article Nutrition education: linking research, theory, and practice.

[2] Jung MS, Bae JH, Kim YH. Relationships between dietary intake and serum lipid profile of subjects who visited health promotion center. J Korean Soc Food Sci Nutr. 2008; 37: $1583-1588$

[3] Ministry of Health and Welfare. Report on 2005 National health and nutrition survey. Ministry of Health and Welfare; 2006.

[4] Van Gaal L, Vansant G, Van Campenhout G, Lepoutre L, De Leeuw I. Apolipoprotein concentrations in obese subjects with upper and lower body fat mass distribution. Int J Obes. 1989; 13: 255-26.

[5] Jennifer Warwick, Heather McIlveen and Christopher Strugnell (1999). Food choices of 9-17 year olds in northern Ireland - influences and challenges. Nutrition and food science, 1999 (5): p. 229-236.

[6] Nutrition in lifecycle: adolescent. Retrieved from the World wide web on 13/1/2003 www.fcs.okstate.edu/ food/nutrition/lifecycle/adolescentcont.

[7] Wei Lin, Hsiao-Chi Yang, Chi-Ming Hang et. al. Nutrition knowledge, attitude, and behavior of Taiwanese elementary school children. Asia Pac J Clin Nutr 2007; 16 (S2): 534-546 534 .

[8] Mary L. Blackburn Marilyn S. Townsend, CaliforniaAgriculture 60 (1): 20-24. DOI: 10.3733/ca. v060n01p20. January-March 2006.

[9] Constance Young (1999), Exercise: like breathing and brushing your teeth. The female patient supplement 1999. P 510 .

[10] Adolescent and school health. Retieved from the World wide web on 13/1/2203 www.cdc.gov/ nccdphp/ healthtopics/nutrition/guidelines/facthtml.

[11] Elizabeth B. Hurlock (1967) chapter 5. Adolescent development. $3^{\text {rd }}$ ed /series in psychology New York P. 335-337. 
[12] Marilyn S. Townsend, Margaret Johns, Mical Kay Shilts, et. al. Evaluation of a USDA Nutrition Education Program for Low-income Youth.

[13] Temple NJ: Organized medicine. An ounce of prevention or a pound of cure. In Temple NJ, Burkitt DB (eds): "Western Disease: Their Dietary Prevention and Reversibility." Totowa, NJ: Humana, pp 381-398, 1994.

[14] Annie S. Anderson, Sally Macintyre and Patrick West (1994) British Journal of Nutrition 71, p. 111-122.

[15] Jennifer A. Hutchison. (2002). "Rural and urban differences between adolescent females" perceptions of body image Retrieved from the World Wide Web on 13/1/2003. www.Faculty.mckendree.edu/ scholars/2202/hutchison.htm

[16] Feldman EB: Networks for medical nutrition education- a review of the US experience and future prospects. Am J Clin Nutr 62: 512-517, 1995.
[17] Norman J. Temple, PhD Survey of Nutrition Knowledge of Canadian Physicians. Journal of the American College of Nutrition 27 Nutrition Knowledge of Canadian Journal of the American College of Nutrition, Vol. 18, No. 1, 26-29 (1999).

[18] Sharma., Sonika and Paramjit K. Chawla. 2005. "Impact of nutritional counseling on anthropometric and biochemical parameters of school girls (7-9 years)." Anthropologist, 7 (2): 121-125.

[19] Gopalan, C., B. V. Shastri and S. C. Balasubramanian. 1989. Nutritive Value of Indian Foods, Indian Council of Medical Research, Hyderabad: National Institute of Nutrition.

[20] Chawla, S. 1992. Effect of Nutritional Status on Physical Work Capacity of School Going Girls. M. Sc. thesis (unpublished) Ludhiana, PAU.

[21] Malhotra, A. and S. J. Passi. 2007. "Diet quality and nutritional status of rural adolescent girls beneficiaries of ICDS in north India.” Asia Pac. J. Nutr., 16 suppl: 8-16. 